\title{
African Christian Inculturation Project: Theological Motifs of Liberation and Decolonization ${ }^{1}$
}

\author{
Malith Kur, McGill University
}

\begin{abstract}
This paper discusses the African Christian theology of inculturation. The theology of inculturation - the African indigenization of Christianity - is one of the African theological movements advocating for the liberation and decolonization of African religious, cultural, and political thought. It is a theological motif that emerged from the African experience of suffering and political and cultural denigration under European colonialism. This paper argues that the African theology of inculturation is a theological outlook that addresses African political, spiritual, and social conditions in the post-colonial era. It is modest and transformative because it offers hope to Africans and empowers them to seek positive change and inclusion, while rejecting a narrative of religious and cultural dominance. It demands recognition of Africa and its cultures by the West as an equal stakeholder in Christ's victory on the cross. The African theology of inculturation expresses a unique African response to the gospel of salvation; in other words, Christian Scriptures are read and interpreted in line with African values, which situate Christian theology in the African cultural and cosmological worldview. The African cosmological worldview takes African indigenous cultures and philosophy as instruments that explain to Africans the relationship between Christianity and the realities of political and religious life in Africa.
\end{abstract}

Keywords: Inculturation Theology; Indigenization; Africanism; Decolonization; Theology of the Cross

I n the context of this paper, Christianity is to be understood as a non-indigenous religion that has influenced certain aspects of African culture, traditions and social life for well over two millennia. In modern day Egypt and Ethiopia, we encounter deeply rooted Coptic Orthodox ${ }^{2}$ Christian traditions within the everyday landscape. For many centuries prior to the Islamic invasion of Sudan in the sixteenth century, the Christian Orthodox Church was perceived as the state religion in ancient Nubia. The Islamic conquest of the region led to the collapse of Nubian Christian kingdoms; however, Orthodox Christian religious practices did not disappear entirely from Nubian society, in fact, they have remained prominent to this day. ${ }^{3}$ During the early centuries of the Christian expansion, Christianity was the official state religion of the North African territories. Western scholarship has come to categorize and define this part of the African continent as Middle Eastern; a constructed designation by the West, but North Africa has always been understood as being, and to this day continues to be, the gateway of Europeans into Africa.

1. Paper presented on November 1st, 2019, for the Colloquium "Christian Theology After Christendom." Organized by McGill University's School of Religious Studies and University of Toronto's Emmanuel College.

2. The Coptic Church in Egypt and the Ethiopian Orthodox Church share history and traditions. For centuries, the Ethiopian Orthodox Church operated under the guidance of and adopted Egyptian Coptic rituals, prayers, and services. Both traditions believe that Jesus Christ has only one nature, the divine, rather than the two natures, divine and human, officially established by the Council of Chalcedon in 451 CE. For this reason, the Greek Orthodox labelled them as "Monophysite Christians." 3. See Roland Werner, William Anderson, and Andrew Wheeler, Day of Devastation Day of Contentment: The History of Sudanese Church Across 2000 Years (Nairobi: Paulines Publications Africa, 2000). 
Historically, North Africa was the first center of Christian scholarship and a region from which St. Augustine and other famous Christian leaders and theologians emerged during the early centuries of Christian growth. One could therefore argue that Christianity was an African religion before the gradual emergence of Christendom in Europe. It is this ancient context and longstanding relationship between Africa and Christianity that justifies the current African theological attempts to indigenize Christian beliefs and practices. Despite its long history in the continent, Orthodox Christianity did not establish an enduring impact or apparent influence on social, political, and economic life in Africa beyond Egypt and Ethiopia.

The advent of European colonialism along with European Catholic and Protestant missionaries introduced significant religious, social, cultural, and political changes to Sub-Saharan Africa. It is the arrival of European missionaries in Africa in the eighteenth and nineteenth centuries that brought European Christianity face-to-face with the indigenous cultures of Sub-Saharan Africa. Thus, it is of little surprise that in this region the indigenous inculturation of Christian theology is not only quite prominent, but remains active. African theology of inculturation allows for Christian Scriptures to be read and interpreted in line with the African cultural and cosmological worldview. Such a move is an attempt by African theologians to establish a constructive dialogue between Christianity and African indigenous cultures. African cultures here are no longer considered or perceived as the practices of the "uncivilized savages" but those of God's people. African Christian theologians believe that through a constructive dialogue with indigenous African cultures, Christianity can secure its place in the social context of post-colonial Africa.

This paper will examine and present some important aspects of the African Christian inculturation project for theological development in Africa. Generally, it will demonstrate that the African Christian theology of inculturation seeks to promote constructive dialogue between Christianity and African indigenous cultures. Further, it will briefly highlight the African inculturation project's connection to the post-Christendom theology of the cross that Douglas John Hall advocates. Since Hall's post-Christendom theology of the cross supports a contextual, inclusive, and constructive dialogue between Christianity and the different cultures it encounters, this paper will briefly compare it with the theologies of the colonial church in Africa. Because Hall's "Theology of the Cross"4 is a unique post-colonial Western Liberation theology, it will allow this discussion to shed light on the influence, function, and purpose of the African Christian inculturation project and how it approaches the task of promoting constructive dialogues. The paper will then proceed to examine the African Christian inculturation project. It will conclude by examining the theological implications of the inculturation project in the modern African context and how this project will provide Africans with a theological framework meant to unite rather than divide.

\section{Douglas John Hall's Theology of the Cross vs. the Theology of the Colonial Church in Africa}

Douglas John Hall is a Canadian theologian and pastor of the United Church of Canada. His theological journey took him to Union Seminary in New York, where he received his Th.D. in 1963. At Union Seminary, he was taught by well-known theologians such as Paul Tillich and Reinhold Niebuhr (as well as several others). After he graduated from Union Seminary, he taught at the University of Waterloo in Ontario and St. Andrew's College at the University of Saskatchewan. He moved to McGill in 1975 as a professor of systematic theology.

4. "Theology of the Cross" points to essential elements of Christian teaching. The first one is the incarnation, which directs Christians toward God in human flesh. The second element is that the incarnate God was crucified and died like one of us, but he overcame death and rose to life, indicating God's ultimate victory over suffering and death. 
The 1960s, 70s, and early 80s were marked by decades of intense Cold War propaganda and ideological competition between communism and Western capitalism. The 1960s witnessed the events of Vatican II, where a shift in the relationship between the Catholic Church, other Christian denominations, and non-Christian religious traditions emerged. Vatican II recognized the validity of other Christian traditions so long as these traditions professed the truth about the living God. ${ }^{5}$ It is at this critical historical moment that Douglas John Hall developed his unique contextual theology of the cross. This theological outlook sees the world, not through the lens of power or domination, but through the lens of humility and inclusivity, whereby there is an attempt to accommodate ideas and views that sit outside what is deemed normative in conservative Christian circles. Hall is not ideologically bent in his writings, and has distinguished himself as an independent theological thinker who uses a non-partisan form of reasoning to free his theological ideas from ideological manipulations. ${ }^{6}$ This intellectual stand makes Hall an influential Canadian theological figure.

Writing in the Anglican Journal, Wayne Holst places Hall's theological perspective in the category of what he calls "intelligent faith," a framework in which theological ideas continue to retain their original meaning and function regardless of "time and place." Intelligent faith does not draw thick borders between people; rather, it illuminates what is useful and appropriate in all cultures and traditions with the intent to create a discourse that will benefit all. It maintains that cultural changes would always occur in the world. Still, Christian traditions must find ways to adapt to those changes without losing their original intentions without compelling anyone to lose their cultural identity. These features give Hall's theology of the cross a uniquely universal appeal, which sets it apart from other Western Liberation Theologies. Black American Liberation Theology ${ }^{8}$ deals with problems facing Blacks in the Americas. For instance, Black Liberation Theologian James H. Core uses the Christian Scriptures to articulate social issues that have demeaned black Americans' lives, but whatever happens in Africa or elsewhere is secondary. ${ }^{9}$

Hall's theology of the cross is "ever new" and "transformative," which allows individuals and communities an opportunity to make informed choices and to adapt to the social and cultural changes around them. ${ }^{10}$ It encourages Christians to address with humility the social conditions under which the gospel's message is proclaimed, and urges the church to seek positive change and inclusivity, not dominance. ${ }^{11}$ Arguably, a positive change in the context of Hall's theology of the cross is a process through which individuals or communities have a choice to maintain their indigenous social and cultural integrity as they encounter Christianity.

\footnotetext{
5. "The truth about the living God" refers to biblical truth (revealed Scripture) and other established Christian teachings or traditions. The truth about the living God here also points to other Abrahamic faith traditions, such as Judaism and Islam. These three traditions are referred to as "Abrahamic Faiths" because their founders are all Abraham's descendants. Furthermore, they are called "religions of the book," for they use the texts containing God's revealed truth (Torah, Bible, and Quran).

6. Douglas John Hall, Douglas John Hall: Collected Readings, ed. David B Lott (Minneapolis: Fortress Press, 2013).

7. Wayne Holst, "Douglas John Hall - Developing Intelligent Faith in a Canadian Context," Anglican Journal, January 17, 2018, https://www.anglicanjournal.com/douglas-john-hall-developing-intelligent-faith-canadian-context/.

8. Black American Liberation Theology has firm roots in African slavery in the USA. It reached its height during the Civil Rights Movement of the 1960s. Black Liberation Theology challenged the policies of a nation founded on the JudeoChristian traditions, which profess that all people are created in the image of God. Yet, America acted contrary to its founding Judeo-Christian values and placed other children of God under the chains of slavery and racial segregation.

9. See James H. Core, A Black Theology of Liberation, 20th-anniversary ed. (Maryknoll, NY: Orbis Books, 1990).

10. Douglas John Hall, God and Human Suffering: An Exercise in the Theology of the Cross (Minneapolis: Augsburg Pub. House, 1986).

11. Hall, God and Human Suffering.
} 
However, it is important to note that all of this stands in stark contrast with the missionary work in the eighteenth and nineteenth centuries that brought the Christian church's European missionaries to Africa with the intent to dominate. The colonial churches that came to Africa showed great arrogance and believed themselves to be culturally superior. This attitude was reflected in their activities, activities which were motivated and guided by European political and economic interest in Africa. The Christian church, through a Eurocentric religious education system, sought to transform and "civilize" Africans so that they too could become like Europeans. It is this goal of "transforming" the African continent which led to the promotion of colonial European interests in Africa. These missionary activities provoked political and theological resistance across the continent because of their complicity with the goals and agenda of European colonial powers in Africa - which only sought the maximum exploitation of Africa's human and material resources.

Therefore, the Christian church in Africa was perceived as a European colonial church, a cult of European conquerors who sought to dominate Africa. This fact is further supported by history, which has recounted how some of the early Christian missionaries participated in the African slave trade and were slave masters themselves. ${ }^{12}$ They were guided by the glory and power of the European colonial empires, not by the humble image of the cross. One African scholar calls it "colonial Christendom," where Christian theological ideas and teachings became instruments of Africa's mass exploitation. ${ }^{13}$

The colonial European Christian missionaries rejected African cultures and religious traditions because they deemed them primitive or associated them with paganism. Such Christianity was not different from that of the Roman Empire or of Christendom, which became "a powerful social force" which transformed communities on its path as it saw fit. ${ }^{14}$ However, in the context of Hall's theology of the cross, such Christianity does not reflect the crucified Christ's humble image. The church that becomes a powerful social force contradicts the cross's message, whose aim is not to strengthen the temporal sources of power but to give the power of love and hope to the weak and the marginalized. ${ }^{15}$

Hall's theology of the cross is dynamic as it encounters new conditions and cultures. Hall's theology can also be understood as reflexive - that is to say, it influences and is influenced by the social conditions and contexts under which its message is delivered. The theology of the cross comes with humility because it does not claim to have the power "to transform our broken world into an instant paradise." 16 As a result, the theology of the cross is not only an emblem of humility but of the suffering and hardship faced in our troubled world. In the presence of suffering and humiliation, the theology of the cross encourages those facing challenges or difficulties to keep faith and trust in the promises of the gospel. It asserts that a positive change will eventually come, not from heaven above but from "within us." 17 A positive change that emerges within us, as individuals or communities, brings social and cultural transformations that promote constructive dialogue, humane values, and attitudes. That is the change that the African theology of inculturation seeks, a change that colonial Christendom failed to implement in Africa.

12. Richard Gray, and Lamin O Sanneh, Christianity, the Papacy, and Mission in Africa (Maryknoll, NY: Orbis Books, 2012).

13. Edward P. Antonio, Inculturation and Postcolonial Discourse in African Theology (New York: Peter Lang, 2006$), 25$.

14. Hall, God and Human Suffering.

15. Hall, God and Human Suffering.

16. Hall, God and Human Suffering, 105.

17. Hall, God and Human Suffering, 105. 


\section{African Theology of Inculturation: A Symbol of Inclusion and Diversity}

The African theology of inculturation views social context, inclusion, and diversity as foundational precepts. It asserts that the cross's message speaks to Africans and other social groups in the context of how to approach their daily lives. The African theology of inculturation promotes the idea that God is present in African indigenous cultures. God's participation in diverse African cultural traditions is reflected in the African inculturation theologians' understanding and interpretation of the biblical expression "Emmanuel: God is with us" (Matt.1: 22-23). "God is with us" is an expression directly embedded in the theology of incarnation. The incarnate God is with us regardless of our faith or beliefs. He is with us regardless of our social and economic status. It affirms that God is in me and speaks to me in the environment in which I live. The incarnate God is a God of all cultures. He knows my language and speaks to me directly. This is where the idea of inclusion and adaptation come into play within Christianity - which Hall's contextual theology of the cross expresses. It is a form of Christian theology that the African Christian inculturation project has embraced as an instrument of theological dialogue and tool for positive social change in postcolonial Africa.

Post-colonial Africa is a community of diverse cultures, faiths, and political thoughts. Over centuries Africa has absorbed various religious traditions and multiple cultural practices from different parts of the world, thus creating a diverse Africa today. For African inculturation theologians, the root of these ideas and principles is not an issue. The important thing is the respect they show toward indigenous African practices and their ability to encourage inclusion, to accommodate diversity, and to help support and build the foundations for independent African social, political, religious, and cultural identities. The concepts of inclusion and accommodation here represent the ability to recognize and accept diversity. In the context of the African inculturation project, these concepts ask that Christians in all cultural settings be aware that the Christian church belongs to all cultures. Hence, others will always have the right to join them at any given time, not only bringing their ideas and ways of life with them, but allowing these differences to continue to be a part of who they are. Hence allowing the African people to choose and not to be subject to cultural or social changes they do not want. Although they may become Christians, they must always remain Africans.

Christianity has proven to be incredibly resilient and has travelled to all four corners of the world, encountering diverse cultures, traditions, and practices. If Christianity was a strictly a dominating power, then it would not have survived or strived in those meeting points, thus proving that it is indeed a religion which can accept diversity. The early Christians were confronted firsthand with the diverse nature of the Christian community on the Day of Pentecost. The story in the book of Acts recounts how people from different regions of the world experienced the coming of the Holy Spirit and began to speak in various "tongues or languages" (Acts 2: 4). In this context, the first Christians witnessed God's action directed to all peoples irrespective of their cultural backgrounds, God did not discriminate all were included in the reception of his blessing. The people who experienced the Holy Spirit's coming to Jerusalem on the Day of Pentecost were Jews, Asians, Africans, and a variety of other ethnic groups. Therefore, Christianity started in the Holy Land as a religion of diverse people with different cultures, traditions and practices, a theological assertion that is supported and promoted by the African Christian inculturation project.

Saint Paul, in his elaborate theological teachings, confirms the same point. He notes that the church, "Christ's body," has many members who perform different functions and activities (1Cor. 12: 1-31). They use their diverse skills and knowledge to support the church's wellbeing, and none of them is less important than the others. This Pauline presentation of the church is reflective of the various cultural activities and practices that Christianity is confronted with in every community or society it encounters. All of this points 
to theological inclusion and to the ability of Christianity to accommodate different cultural practices and values which strengthen and promote Christian growth throughout the world.

African theologians Dom Nwachukwu and Peter Nlemadim have underlined the importance of the inculturation project in Africa. In their study of the Igbo Christian community in Nigeria, they observe that to achieve "authentic Igbo Christianity, the Igbo must hear the Christian message in a language they can understand and metaphors that are native to them." ${ }^{18}$ Their observation suggests that in order for a Christian community to meet the needs of their believers they must allow their members to use their cultural tools to discover what the gospel is saying to them. It means that for the Igbo people to make sense of the promises that the gospel makes to them, they must do so by studying the Christian scriptures and interpreting them through their culture, practices, and traditions, through their ways of life. This observation is not only appropriate for the Igbo community in Nigeria but for the rest of Africa as well. It is an essential component that is needed in order to ensure the dialogue between African indigenous cultures and Christianity; it is the core of the African Christian inculturation project. In other words, it is an attempt by the African Christian theologians to implement the indigenization of Christianity in Africa. They want Christianity to become an indigenous or a traditional African religion that will serve African cultural and spiritual needs.

The African Christian theology of inculturation encourages and promotes inclusivity. It maintains the principle that every cultural heritage has something to offer because it is part of God's plan for the world. This inclusive theological principle can - as already seen in Africa- allow for a greater number of communities and societies to be receptive to the message of the cross and transform these communities in a way that best fits their cultural and spiritual needs. The crucial point to note is that once the message of the cross is accepted within a community it brings cultural transformation unique to that community. Thus, it becomes a distinct Christian community, which employs its indigenous worldview to promote Christian values and beliefs.

Recent research by Jesse Zink speaks to a situation in South Sudan in the 1990s, where indigenous actors actively promoted Christian religious practices amid difficult social challenges. ${ }^{19}$ Some "uneducated indigenous Christian prophets and evangelists" spread the gospel message of hope in their rural communities, a development that created distinctly indigenous South Sudanese Christian communities of various Christian denominations. ${ }^{20}$ Ideas within African Christian inculturation - especially the use of indigenous religious metaphors, such as raan Nhialic, which means man of God - inspired and enhanced the ability of those uneducated indigenous prophets and evangelists to spread the gospel message. They connected the biblical prophetic traditions with their own and began to interpret biblical stories in relation to local ways of life. Today, South Sudanese communities use their cultural heritage to promote and proclaim the gospel's message of hope and positive change. They have vernacularized the gospel through songs and dance to help them understand God's relationship with the whole creation. These theological developments suggest that every cultural heritage in the world has an essential role in teaching and spreading the Christian message of salvation. That is the claim that the African Christian inculturation project has put forward.

In this context, we can talk about a distinct African Christianity or a distinct African Christian community. A distinct African Christianity is the one that respects and values the indigenous cultural heri-

18. Peter Nlemadim DomNwachukwu, Authentic African Christianity: An Inculturation Model for the Igbo (New York: P. Lang, 2000), 8.

19. Jesse Zink, Christianity and Catastrophe in South Sudan: Civil War, Migration, and the Rise of Dinka Anglicanism (Texas: Baylor University Press, 2018).

20. Zink, Christianity and Catastrophe. 
tage of the African people. At the same time, the African Christian community has gained an interpretative right and shares in the formation of what the message of the gospel means to them. The indigenous heritage allows the African community to build its very own special relationship with Jesus Christ as the savior and the Firstborn of all creation. That is the aim and goal of the Christian inculturation project in Africa; it is a social and theological movement striving to indigenize Christianity to address African social needs. It is an inward-looking theological project that shares similarities with the Liberation Theology movement, a movement which takes a stand in favor of the oppressed and marginalized and fights for their political, social, and economic rights. ${ }^{21}$

The concept of liberation in the context of the African theology of inculturation supports the theological liberty and freedom for Africans to examine Christian Scriptures in relation to their cosmological worldview. In recent years, African Christian theologians have begun to explain some Christian theological ideas and teachings using African indigenous spiritual metaphors and analogies. They look, for example, at the veneration of Christian Saints as comparable to the veneration of ancestors. We know that Christian saints are ordinary Christian believers who, in their service to the church, made significant contributions to building and promoting Christian faith and values. Christians honor them for their faithfulness, service, and dedication to the Christian faith. Similarly, ancestors in various African cultures are individuals or indigenous religious figures who made significant efforts to establish clans and ethnic communities. After their death, they are considered to have entered the spiritual world, and, in the process, acquired even greater powers and are understood as forces for good or evil. Members of the community continue to look for their guidance, but, at the same time, the community must always appease them to mediate or intercede to God on their behalf. ${ }^{22}$ Therefore, ancestors are like saints in the Christian theological context. African theologians therefore use the similarity between ancestral veneration and sainthood to explain the idea behind sainthood in Christian doctrines. This usage functions as an essential way to vernacularize and decolonize Christian theological terms to meet the African Christian inculturation project's requirements.

Moreover, African inculturation theologians today refer to Jesus Christ as "the Great Ancestor," which has generated the concept of "ancestral Christology." ${ }^{23}$ The idea of the Great Ancestor emphasizes Christ's role as the mediator between God and humanity. An ancestor is recognized as a founder or root of the community. Furthermore, his actions are considered to have facilitated the growth and wellbeing of his descendants. In African indigenous perception, death does not diminish the natural personal relationship between the ancestors and their descendants. In fact, it gives this relationship a special meaning and significance since ancestors become closer to God after departing this life.

Advocates of the inculturation project encourage the use of "healing ceremonies, beating of drums, and dancing to the traditional African rhythms" in African Christian worships. ${ }^{24}$ These practices are an essential part of incorporating Christian rituals within the African cultural contexts to give them an African quality. Dancing and beating drums during Christian worship ceremonies give ordinary African Christians the ability to connect and become real participants and Christian church members. African incultur-

21. S. S. Maimela, "Black Theology and the Quest for a God of Liberation," Journal of Theology for Southern Africa 7, no. 82 (1993): 54-66.

22. Jaco Beyers, and Dora N. Mphahlele, "Jesus Christ As Ancestor: An African Christian Understanding," Hts Teologiese Studies / Theological Studies 65, no. 1 (2009): https://doi.org/10.4102/hts.v65i1.132.

23. Beyers and Mphahlele, "Jesus Christ as Ancestor."

24. Badra Lahouel, "Ethiopianism and African Nationalism in South Africa Before 1937," Cahiers D'Études Africaines 26, no. 104 (1986): 681-688, http://www.jstor.org/stable/4392069. 
ation theologians also demand the incorporation of African "stories and proverbs in the study" of the Bible. ${ }^{25}$ For instance, let us compare the following texts:

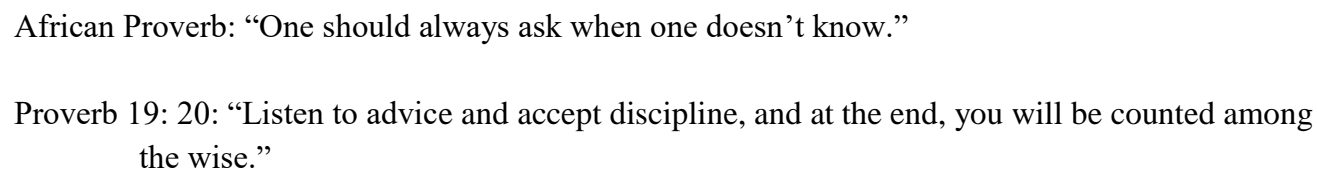

Both texts emphasize that people gain knowledge or wisdom by seeking counsel from those who are knowledgeable. Although the two statements are not necessarily the same, they do not contradict each other. They offer the reader instruction on how to seek knowledge and understanding. The benefit of using the African indigenous wisdom literature in the study of the Bible is that it allows the average African Christian to identify with the biblical text and to connect scripture with the affairs of one's daily life. That is why some African scholars, such as John Mbiti ${ }^{26}$ and others, not only encourage but demand that African indigenous resources be applied to the study and interpretation of Christian Scriptures. Therefore, the incorporation of indigenous practices and sayings is an essential part of the indigenization and inclusivity project. Such activities have enabled fruitful dialogue between Christianity and indigenous African perception and understanding of scripture, which have in turn enriched the Christian gospel message. They have also helped average African Christian believers with limited exposure to biblical texts to further examine those texts and better understand them.

\section{The Theological Implications of the Christian Inculturation Project in Africa}

The inculturation project began in Africa as a response to European political, economic, and religious colonialism. However, the post-colonial agenda of neocolonialism and neoliberalism's policies place strains on the functions and activities of the inculturation project. Indeed, neocolonialism and neoliberalism's ideologies, whether in political or religious discourses, significantly diminish the influence of the African inculturation project, but they will not be addressed here. They are beyond the scope of this discussion. Suffice it to say that post-colonial agendas only hinder the progress and goals of projects which seek to implement inclusionary models and individual freedom within the various African communities. ${ }^{27}$ The theology of inculturation has many implications that have influenced the religious and cultural relationships between Africa and the Western world. First, it has facilitated the infusion of Christianity into what an African religious scholar A. O. Balcomb calls the African "habitus" or the African philosophical and spiritual consciousness. ${ }^{28}$

The transformation and molding of Christian theological teachings and/or doctrines using the African indigenous knowledge system has helped many indigenous African communities to understand Christian traditions and values. It has opened the way for the infusion of Christianity into the African cons-

25. Willie Van Heerden, “"The Proverb Is the Drum of God': On the Use of African Proverbs in the Interaction between African Culture and the Christian Faith," Scriptura: International Journal of Bible, Religion and Theology in Southern Africa 81, no. 1 (2002): 462-475, https://doi.org/10.7833/81-0-748.

26. See John S. Mbiti, African Religions \& Philosophy, 2nd rev. ed. (Oxford: Heinemann, 1990).

27. See Obianuju Ekeocha, Target Africa: Ideological Neocolonialism in the Twenty-First Century (Ignatius Press, 2018); Kenneth C. Omeje, ed., The Crises of Postcoloniality in Africa (Baltimore, MD: Project Muse, 2018).

28. A. O. Balcomb, "Theological Education in South Africa and the Epistemological Divide: In Search of the African Habitus," Scriptura: International Journal of Bible, Religion and Theology in Southern Africa 114, no. 1 (2015): 1-12, https://hdl.handle.net/10520/EJC171259. 
ciousness by using African indigenous resources. This reality has promoted the rapid growth of Christianity in Sub-Saharan Africa, and it is projected that the Christian population in Africa will reach over half a billion people by $2025 .^{29}$ As many religious scholars have noted, this exponential growth in Africa is indicative of a shift in "the center of gravity" of Christian religious influence from the Northern hemispheres to the South. ${ }^{30}$ These changes are, in part, thanks to the ideas promoted by Christian inculturation theology and the post-Christendom theology of the cross, their focus on inclusion and accommodation. Thus, the inculturation theology project makes Christianity an essential part of African spiritual, social, and political capital, allowing indigenized African Christianity to support freedom in the post-colonial political environment of Sub-Saharan Africa. These ideas of inclusion and accommodation have introduced and immersed the gospel into the African way of life. The important point of this discourse is not only about how the Christian gospel has changed Africa, but also how African cultures have transformed the gospel's narratives to become a significant part of African modern religious and political life. ${ }^{31}$

The African theology of inculturation expresses a unique African response to the gospel of salvation; in other words, Christian Scriptures are read and interpreted in line with African values and practices which place Christian theology in the context of the African cultural and cosmological worldview. The African cosmological worldview cherishes the relationship between the Creator and the world through the ancestors and other spiritual mediating forces. It utilizes African indigenous culture and philosophy as hermeneutical instruments to explain to Africans the relationship between Christianity and the realities of political and religious life in Africa. Africa is no longer ready to remain a passive recipient of Western or Eastern theological ideas, but is a contributor to the ongoing development of Christian theology using its indigenous resources.

In addition, the African theology of inculturation is a theological motif of resistance that emerged in the African experience of suffering and the denigration of African political, religious, and cultural elements under European colonialism. It is driven by the belief in Africanism, that is, the claim that black Africans and their cultural practices must play a significant role in African affairs. ${ }^{32}$ The project's advocates are convinced that Africanism should be the means through which African values and practices - once undermined by European colonial exploitation - are be revived, promoted, and reasserted. The aim is to liberate and decolonize African religious, cultural, political thought and consciousness in the twenty-first century. The African theology of inculturation encourages Africans to claim the message of the gospel and to own it; these claims are all in line with the fundamentals of liberation theology and of Hall's postChristendom theology of the cross, which considers Christianity as a religion of diversity and inclusion. The aim of the inculturation project is to try and encourage Africa to claim its rightful place in the religious, political, and cultural landscape of the modern world. The modern world is rapidly changing, but the African inculturation project's message to all Africans is that they must not lose sight of their cultural heritage. That is an important message because the secrets of building up Africa will not come from Europe or elsewhere but from Africa itself.

29. Balcomb, "Theological Education in South."

30. See International Annual Conference of the German Operations Research Society (2012: Leibniz Universitat), Operations Research Proceedings 2012: Selected Papers of the International Annual Conference of the German Operations Research Society (Gor). Leibniz University of Hannover, Germany, September 5-7, 2012, ed. Stefan Helber (Cham: Springer, 2014).

31. Balcomb, "Theological Education in South Africa."

32. Antonio, Inculturation and Postcolonial Discourse, 1. 


\section{African Inculturation Project and the Positive Aspects of European Christian Missionaries}

Despite the generally negative views held by the inculturation project about European colonialism in Africa, it does not deny some of the positive contributions left behind by the colonial church in the African continent. According to the African theologian A. O. Balcomb, the rapid growth of Christianity in Sub-Saharan Africa has its roots in a host of positive and constructive elements that the church left during its missionary period in Africa. Education is one of these positive elements. As was always the case in Europe and other Western societies, there was substantial "association of Christian missions with education" in Africa during the colonial period. ${ }^{33}$ Although Balcomb recognizes the essential role that education has played in building a healthy relationship between Christianity and African societies, he does not believe that the Christian mission to educate provides a convincing argument for explaining the Christian faith's rapid development and growth in Africa. Instead, he suggests another explanation, one which he calls the "epistemological explanation," and argues that this explanation is the best way to understand the rapid growth of Christianity in the African continent. ${ }^{34} \mathrm{He}$ adopts the view that Christianity offers Africans the best theological interpretation of the world, in part thanks to Christian "poems and songs." ${ }^{35}$ The premise here is that Africans discovered the real religious meaning in European Christian songs. The singing Christian missionaries introduced into African religious life profoundly appealed to Africans, since songs are often the medium that connect Africans to the spiritual world. Hence, Christian songs are at the foundation of African Christian spirituality.

Although Balcomb makes an interesting point by highlighting the possible role played by imported poems and songs, I am not convinced by his argument. There is no doubt that songs and other Christian rituals have had a significant influence on Africans; however, dancing, singing, and poetry have always been a core of African religious and cultural practices. In indigenous religious settings, songs and poems function as instruments or mediums of prophecy that allow Africans to communicate with the ancestors and other spiritual forces. They sit at the center of African art and philosophy. Consequently, European Christian songs and poems alone cannot adequately explain the Africans' move to embrace Christianity. As a result, if we pay close attention to the African landscape today, we cannot overlook education's role. During the colonial era, the relationship between Christianity and African societies was primarily practical, not spiritual. Access to certain services, such as healthcare and education, was vital for this relationship to flourish and remain in good condition. The Christian mission's focus on education built the bridges that allowed the African souls to absorb gospel songs and poems written in European languages. Indeed, the generations of African theologians, anthropologists, and social scientists educated at missionary institutions have appropriated European Christian art and philosophy through education. They have given it an African theological, political, and social dimension to better integrate their cultural milieu. As we speak, most Africans are literate in major European languages because they are the means by which knowledge and instruction are disseminated in schools and colleges across Africa. They also serve as official means of communication in government institutions. Therefore, the association of mission education with all the areas of modern learning across Sub-Saharan Africa remains, in my view, a critical factor in Christianity's expansion in the region.

Christian educational endeavors in Africa allowed average Africans, especially the youth, to access and participate in social life across the sub-continent. These elements positioned Christianity to be viewed

33. Balcomb, "Theological Education in South Africa," 2.

34. Balcomb, "Theological Education in South Africa," 2.

35. Balcomb, "Theological Education in South Africa," 2. 
by Africans in a positive way. Christianity was thus presented as a religion that serves ordinary people. This reality has not only continued to attract young Africans but has become how Christianity has rapidly spread throughout the various communities within Africa. Christian education in Africa has played a decisive role in the training and producing of African indigenous scholars who have accepted the responsibility of reasserting the African identity. Through the project of inculturation, Africans are making their voices heard. However, indigenous African scholarship has not rejected outside ideas, but rather has embraced and used them to support and promote the African view of the world.

\section{Conclusions}

This article has explored some aspects of the African Christian theology of inculturation. It has also offered a brief comparison between Douglas John Hall's theology of the cross and the theologies of the colonial church in Africa to highlight their differences. Both the African inculturation project and Hall's theology of the cross support and promote the principles of dialogue between Christianity and the various cultural practices it encounters throughout the world. This approach places an emphasis on inclusion and accommodation as integral parts of this dialogue. The universal appeal of Hall's theology of the cross for reasonable theological discourse has the potential to lay a solid foundation of understanding between Christianity and indigenous cultures worldwide. It would allow some Christians to see ideas, values, and virtues in non-traditional Christian manner, which may help spread and teach Christian principles. For example, the indigenous African post-colonial approach to Christian theology has created momentum for a rapid Christian expansion in Africa. African Christian theologians use the moral teaching of the ancestors and other forms of indigenous knowledge systems to study and understand Christian values and beliefs. This development demonstrates that the post-colonial church in Africa sees dialogue with local cultures as the right way to exchange theological ideas for the benefit of all. It also reduces tensions with local religious actors. This gesture allows indigenous people to realize that Christianity is not a threat to their values and practices. Whereas, in the colonial church, African theological ideas and innovations were suppressed and considered immoral or sinful because of their association with African cultural practices. Hence, this reality highlights a significant difference in approach between the colonial and post-colonial churches in Africa and elsewhere.

The African Christian theology of inculturation regards theological thinking as an essential part of God's gift to all peoples. For this reason, it has provided a framework for post-colonial religious institutions in Africa to take a stand and reassert the fundamentals of Africanism. Africanism's concept suggests that African values and cultural practices can teach Africans of all religious backgrounds about God and his plans for humanity. It has exposed the neocolonial religious agenda that still considers African indigenous spiritual practices as pagan. This group includes Pentecostal churches and other Christian fundamentalists. The inculturation project has outlined an essential program for the reassertion of the African cultural identity on the global stage and minimized the cultural changes that European imperialism introduced into African social life.

Today, the African inculturation project has taken steps to ensure that Africa contributes to matters associated with developing theological discourse. They include promoting the teaching of the African indigenous religions in various Christian seminaries across the continent. Part of this is to re-examine Africa's old relationship with Christianity, and to recognize that Africa has made significant contributions to the development of the Christian religion. For example, the Bible tells us that Africa hosted an infant Jesus when his parents fled King Herod's terror in Jerusalem (Matt 2: 13-23). As a child, Jesus was welco- 
med with open arms in Egypt and enjoyed the hospitality of the African indigenous cultures. Therefore, Africa was the first home to Christianity. During the early centuries of the Christian expansion, Alexandria in Egypt and other cities in North Africa became significant centers for Christian theological education. Christianity is not new to Africa, and its rapid growth throughout the continent today is not a surprise. The African Christian inculturation project points to these historical realities to reaffirm that Africa and its cultures still have more to offer to Christian theological development.

Douglas John Hall's theology of the cross recognizes the contributions of African indigenous practices and other non-Western cultures to the development and promotion of Christian values and beliefs. That is why it calls for the inclusion and accommodation of non-Western theological ideas in Christian theological discourses. It is a recognition that every culture is a gift from God and must be allowed to participate in all the acts of praise and worship as long as they respect and maintain the truth about the living God. 


\section{Bibliography}

Antonio, Edward P. Inculturation and Postcolonial Discourse in African Theology. New York: Peter Lang, 2006.

Balcomb, A. O. "Theological Education in South Africa and the Epistemological Divide: In Search of the African Habitus." Scriptura: International Journal of Bible, Religion and Theology in Southern Africa 114, no. 1 (2015): 1-12. https://hdl.handle.net/10520/EJC171259.

Beyers, Jaco, and Dora N. Mphahlele. "Jesus Christ As Ancestor: An African Christian Understanding." Hts Teologiese Studies / Theological Studies, 65, no. 1 (2009). https://doi.org/10.4102 hts.v65i1.132.

Core, James H. A Black Theology of Liberation. 20th-anniversary edition. Maryknoll, NY: Orbis Books, 1990.

DomNwachukwu, Peter Nlemadim. Authentic African Christianity: An Inculturation Model for the Igbo. New York: P. Lang, 2000.

Ekeocha, Obianuju. Target Africa: Ideological Neocolonialism in the Twenty-First Century. Ignatius Press, 2018.

Gray, Richard, and Lamin O. Sanneh. Christianity, the Papacy, and Mission in Africa. Maryknoll, N.Y.: Orbis Books, 2012.

Hall, Douglas John. God and Human Suffering: An Exercise in the Theology of the Cross. Minneapolis: Augsburg Pub. House, 1986.

—. Douglas John Hall: Collected Readings. Edited by David B Lott. Minneapolis: Fortress Press, 2013.

Holst, Wayne. "Douglas John Hall - Developing Intelligent Faith in a Canadian Context." Anglican Journal, January 17, 2018. https://www.anglicanjournal.com/douglas-john-hall-developingintelligent-faith-canadian-context/.

International Annual Conference of the German Operations Research Society (2012: Leibniz Universitat). Operations Research Proceedings 2012: Selected Papers of the International Annual Conference of the German Operations Research Society (Gor). Leibniz University of Hannover, Germany, September 5-7, 2012. Edited by Stefan Helber. Cham: Springer, 2014.

Lahouel, Badra. "Ethiopianism and African Nationalism in South Africa Before 1937." Cahiers D'Études Africaines 26, no. 104 (1986): 681-688. http://www.jstor.org/stable/4392069. 
Maimela, S. S. "Black Theology and the Quest for a God of Liberation." Journal of Theology for Southern Africa 7, no. 82 (1993): 54-66.

Mbiti, John S. African Religions \& Philosophy. 2nd revised edition. Oxford: Heinemann, 1990.

Omeje, Kenneth C., ed. The Crises of Postcoloniality in Africa. Baltimore, MD: Project Muse, 2018.

Van Heerden, Willie “"The Proverb Is the Drum of God': On the Use of African Proverbs in the Interaction between African Culture and the Christian Faith." Scriptura: International Journal of Bible, Religion and Theology in Southern Africa 81, no. 1 (2002): 462-475. https://doi.org/10.7833/810-748.

Werner, Roland, William Anderson, and Andrew Wheeler. Day of Devastation Day of Contentment: The History of Sudanese Church Across 2000 Years. Nairobi: Paulines Publications Africa, 2000.

Zink, Jesse. Christianity and Catastrophe in South Sudan: Civil War, Migration, and the Rise of Dinka Anglicanism. Texas: Baylor University Press, 2018. 